\title{
THE MENTAL FORAMEN - HORIZONTAL POSITION AND SHAPE IN SOUTHEAST SERBIAN POPULATION ${ }^{\star}$
}

\author{
Jelena Popović ${ }^{1}$, Marija Daković Bjelaković ${ }^{2}$, Jovanka Gašić ${ }^{\text {, }}$ Marija Nikolić ${ }^{1}$, \\ Milan Spasić ${ }^{3}$, Aleksandar Mitić ${ }^{1}$, Radomir Barac ${ }^{1}$ \\ ${ }^{1}$ Department of Restorative Dentistry and Endodontics, Clinic of Dentistry, \\ Medical Faculty, University of Niš, Niš, Serbia \\ ${ }^{2}$ Department of Anatomy, Medical Faculty, University of Niš, Niš, Serbia \\ ${ }^{3}$ Department of Oral Surgery, Clinic of Dentistry, Medical Faculty, University of Niš, Niš, Serbia
}

Summary. The mental foramen is an important anatomic landmark not only in dentistry but also in forensics, and the knowledge about its accurate location is important in receiving local anesthesia, during surgical and endodontic procedures. The purpose of this study was to determine the most common position and shape of the mental foramen in the Southeast Serbian population. Three hundred panoramic radiographs were analyzed and the horizontal position of the mental foramen was determined according to the reference lines drawn at the longitudinal axes of the first and the second premolar and the mesial root of the first molar. In $62 \%$ of the cases mental foramen was between longitudinal axes of the first and the second premolar, in $21 \%$ it was in line with the second premolar, in $9 \%$ in line with the first premolar, in $8 \%$ between the axes of the second premolar and the first molar. The most common shape was round $(54 \%)$. The horizontal position and shape were asymmetrical in $26 \%$ and $32 \%$ of the cases, respectively. The most common position of the mental foramen was between the first and the second premolar, while the most common shape was round. Knowledge about variable positions of the mental foramen is important in establishing diagnosis and clinical procedures in the region of the mandible.

Key words: mental foramen, mandible, panoramic radiograph

\section{Introduction}

The mental foramen is an important anatomic landmark in both dentistry and, forensics, and the knowledge about its accurate location is important in receiving local anesthesia, during surgical and endodontic procedures (Khojastepour et al. 2015). Mental nerve and associated blood vessels pass through this foramen. The mental nerve is a terminal branch of the inferior alveolar nerve that supplies sensory innervation of the chin, lower lip, buccal vestibule and gingiva on the ipsilateral side of the mandible (Chkoura and Wady, 2013).

The most commonly used method for studying the position of the mental foramen in everyday practice is the panoramic radiograph since it provides the ability to observe the accurate location of the mental foramen in both horizontal and vertical dimensions (Philips et al. $1992^{2}$ ). The position of the foramen is individual and variable and it could be located from the apex of the canine to the apex of the mesiobuccal root of the mandibular first molar (Philips et al. $1992^{1}$ ). Many researchers have analyzed the position of the mental

Autor za korespondenciju: Jelena Popović, e-mail: jelenadp@gmail.com Klinika za stomatologiju Niš, Bulevar Zorana Đinđića 52, 18000 Niš, Srbija

* The paper was presented at the $54^{\text {th }}$ Congress of the Serbian Anthropological Society held on June 1-4, 2016 in Sremski Karlovci, Serbia 
foramen and shown that the variations among different populations do exist (Hasan, 2010; Santini and Alayan, 2012). Accurate information regarding the horizontal position and shape of the mental foramen have very important clinical significance. Radiograph appearance of the foramen could lead to misdiagnosis of radiolucent periapical lesion in the region of the mandibular premolars. The mental nerve could also been traumatized during overfilling of the root canals and surgical procedures resulting in paresthesia and anesthesia (Greenstein and Tarnow, 2006; Philips et al. 1990).

The purpose of this study was to determine the most common position and shape of the mental foramen in the Southeast Serbian population.

\section{Material and Method}

This sample comprised 300 panoramic radiographs of the patients from the Clinic of Dentistry in Niš taken using a digital Orthopantomograph (Carestream CS 9000). The patients were in position where the head was tilted around $5^{\circ}$ downward in relation to the Frankfort plane.

Three hundred patients (162 males and 138 females) with the mean age 31 (from 18 to 62 years of age) were included in this study. The exclusion criteria were presence of the development anomalies or trauma of the jaws, presence of the missing or impacted teeth between the two first mandibular molars, incomplete eruption of the permanent teeth, presence of the radiolucent or radiopaque lesions in the lower arch and exposure or processing artefacts, patients with history of orthodontic treatment of lower arch crowding and spacing, and under the age of 18.

Each radiograph was carefully analyzed in order to observe the presence and accurate position and shape of the left and right mental foramen. According to Chkoura and Wady (2013), horizontal position of the mental foramen was determined in relation to the three reference lines drawn at the longitudinal axes of the first and the second premolar and the mesial root of the mandibular first molar (Figure 1). According to Al-Shayyab et al. (2015) the shape was recorded as round, oval and irregular. The position and shape were analyzed in relation to the gender and the side of the mandible.

Statistical analysis was carried out using $\chi^{2}$ test. A p value less than 0.05 was considered to be statistically significant.

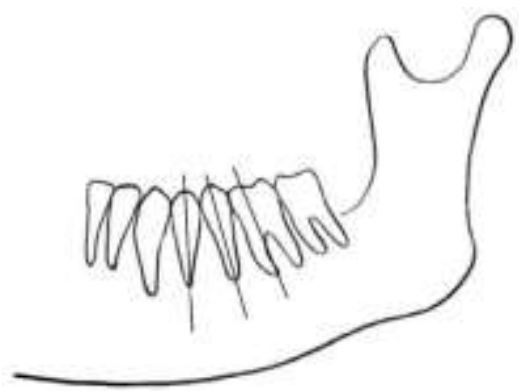

Figure 1. Reference lines for determination of horizontal position of the mental foramen drawn at the longitudinal axes of the mandibular teeth.

Slika 1. Referentne linije za određivanje horizontalne pozicije foramena mentale duž aksijalnih osa donjih zuba. 


\section{Results}

The most common horizontal position of the mental foramen was between the longitudinal axes of the first and the second premolar in $62 \%$ of the cases $(31.66 \%$ for males and $30.33 \%$ for females; $30 \%$ for the left and $32 \%$ for the right side) (Figure 2). In $21 \%$ of the cases the mental foramen was in line with the second premolar (12.33\% for males and $8.66 \%$ for females; $10 \%$ for the left and $11 \%$ for the right side), in $9 \%$ in line with the first premolar (5\% for males and $4 \%$ for females; $5 \%$ for the left and $4 \%$ for the right side), in $8 \%$ between the axes of the second premolar and the first molar (5\% for males and 3\% for females; $4 \%$ for the left and $4 \%$ for the right side). A position anterior to the first premolar was not observed. The horizontal position was asymmetrical in $26 \%$ of the cases. No statistically significant difference in position of the mental foramen was observed between males and females $(p>0.05)$ (Table 1) and between the left and the right side $(\mathrm{p}>0.05)$ (Table 2).

Table 1. Horizontal position of the mental foramina in relation to the gender.

Tabela 1. Horizontalna pozicija foramena mentale u odnosu na pol pacijenata.

\begin{tabular}{lccc}
\hline & $\begin{array}{c}\text { Male n (\%) } \\
\text { Muškarci n (\%) }\end{array}$ & $\begin{array}{c}\text { Female n (\%) } \\
\text { Žene n (\%) }\end{array}$ & $\begin{array}{c}\text { Total n (\%) } \\
\text { Ukupno n (\%) }\end{array}$ \\
\hline $\begin{array}{l}\text { In line with 1st premolar } \\
\begin{array}{l}\text { U nivou I premolara } \\
\text { Between 1st and 2nd premolar }\end{array}\end{array}$ & $15(5)$ & $12(4)$ & $27(9)$ \\
$\begin{array}{l}\text { Između I i II premolara } \\
\text { In line with 2nd premolar }\end{array}$ & $95(31.66)$ & $91(30.33)$ & $186(62)$ \\
$\begin{array}{l}\text { U nivou II premolara } \\
\text { Between 2nd premolar and 1st molar }\end{array}$ & $37(12.33)$ & $26(8.66)$ & $63(21)$ \\
$\begin{array}{l}\text { Između II premolara i I molara } \\
\text { Total n (\%) }\end{array}$ & $15(5)$ & $9(3)$ & $24(8)$ \\
Ukupno n (\%) & $162(54)$ & $138(46)$ & $300(100)$ \\
\hline
\end{tabular}

Table 2. Horizontal position of the mental foramina in relation to the side of the mandible. Tabela 2. Horizontalna pozicija foramena mentale u odnosu na stranu mandibule.

\begin{tabular}{lccc}
\hline & $\begin{array}{c}\text { Left } \mathrm{n}(\%) \\
\text { Levo n (\%) }\end{array}$ & $\begin{array}{c}\text { Right n (\%) } \\
\text { Desno n (\%) }\end{array}$ & $\begin{array}{c}\text { Total n (\%) } \\
\text { Ukupno n (\%) }\end{array}$ \\
\hline $\begin{array}{l}\text { In line with 1st premolar } \\
\begin{array}{l}\text { U nivou I premolara } \\
\text { Between 1st and 2nd premolar }\end{array}\end{array}$ & $15(5)$ & $12(4)$ & $27(9)$ \\
$\begin{array}{l}\text { Između I i II premolara } \\
\begin{array}{l}\text { In line with 2nd premolar } \\
\text { U nivou II premolara }\end{array}\end{array}$ & $90(30)$ & $96(32)$ & $186(62)$ \\
$\begin{array}{l}\text { Between 2nd premolar and 1st molar } \\
\text { Između II premolara i I molara }\end{array}$ & $30(10)$ & $33(11)$ & $63(21)$ \\
\hline $\begin{array}{l}\text { Total n (\%) } \\
\text { Ukupno n (\%) }\end{array}$ & $12(4)$ & $12(4)$ & $24(8)$ \\
\hline
\end{tabular}

The most common shape of the mental foramen was round $(54 \%)(30.66 \%$ for males and $23.33 \%$ for females; $28 \%$ for the left and $26 \%$ for the right side). The oval shape was observed in $39 \%$ of the cases $(21.33 \%$ for males and $17.66 \%$ for females; $18.66 \%$ for the left and $20.33 \%$ for the right side), while $7 \%$ of the patients had irregular shape of the mental foramen (4\% for the males and $3 \%$ for the females; $4 \%$ for the left and $3 \%$ for the 
right side). The shape was asymmetrical in $32 \%$ of the cases. No statistically significant difference was found in the shape of the mental foramen between males and females $(p>0.05)$ (Table 3$)$ and between the left and the right side $(p>0.05)$ (Table 4).

Table 3. Shape of the mental foramina in relaton to the gender.

Tabela 3. Oblik foramena mentale u odnosu na pol pacijenta.

\begin{tabular}{lccc}
\hline & $\begin{array}{c}\text { Male n (\%) } \\
\text { Muškarci n (\%) }\end{array}$ & $\begin{array}{c}\text { Female n (\%) } \\
\text { Žene n (\%) }\end{array}$ & $\begin{array}{c}\text { Total n (\%) } \\
\text { Ukupno n (\%) }\end{array}$ \\
\hline $\begin{array}{l}\text { Round } \\
\text { Okrugao }\end{array}$ & $92(30.66)$ & $70(23.33)$ & $162(54)$ \\
$\begin{array}{l}\text { Oval } \\
\text { Ovalan }\end{array}$ & $64(21.33)$ & $53(17.66)$ & $117(39)$ \\
$\begin{array}{l}\text { Irregular } \\
\text { Nepravilan }\end{array}$ & $12(4)$ & $9(3)$ & $21(7)$ \\
$\begin{array}{l}\text { Total n (\%) } \\
\text { Ukupno n }(\%)\end{array}$ & $162(54)$ & $138(46)$ & $300(100)$ \\
\hline
\end{tabular}

Table 4. Shape of the mental foramina in relation to the side of the mandible.

Tabela 4. Oblik foramena mentale u odnosu na stranu mandibule.

\begin{tabular}{lccc}
\hline & $\begin{array}{c}\text { Left n (\%) } \\
\text { Levo n (\%) }\end{array}$ & $\begin{array}{c}\text { Right n (\%) } \\
\text { Desno n (\%) }\end{array}$ & $\begin{array}{c}\text { Total n (\%) } \\
\text { Ukupno n (\%) }\end{array}$ \\
\hline $\begin{array}{l}\text { Round } \\
\text { Okrugao }\end{array}$ & $84(28)$ & $78(26)$ & $162(54)$ \\
$\begin{array}{l}\text { Oval } \\
\text { Ovalan }\end{array}$ & $56(18.66)$ & $61(20.33)$ & $117(39)$ \\
$\begin{array}{l}\text { Irregular } \\
\text { Nepravilan }\end{array}$ & $12(4)$ & $9(3)$ & $21(7)$ \\
$\begin{array}{l}\text { Total n (\%) } \\
\text { Ukupno n }(\%)\end{array}$ & $150(50)$ & $150(50)$ & $300(100)$ \\
\hline
\end{tabular}

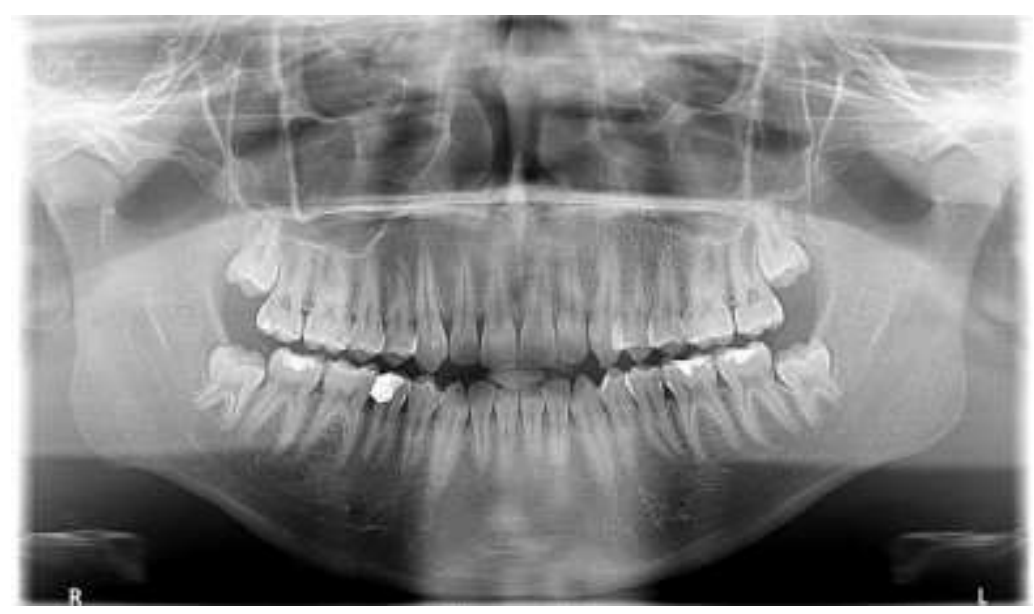

Figure 2. The most common position of the mental foramen in Southeast Serbian population (between the first and the second premolar)

Slika 2. Najčešća pozicija foramena mentale u populaciji jugoistočne Srbije

(između prvog i drugog premolara) 


\section{Discussion}

The knowledge of location of the mental foramen is essential to prevent the mental nerve injury during surgical and endodontic procedures in foraminal area. The injury may lead to temporary or permanent paresthesia or sensory dysfunction of the chin, lower lip and gingiva in the anterior region (Babshet et al. 2015; Berberoglu et al. 2011). Horizontal position and other characteristics of the mental foramen could be studied on dry sculls, radiographs, as well as using computed tomography. The most used noninvasive method of assessing position of the mental foramen is by radiography. Since the foramen is usually below the edge of the film when the intraoral radiography is used, more accurate interpretation of location and shape is allowed by using panoramic radiographs (AlShayyab et al. 2015; Ngeow, 2010). Panoramic radiographs provide the ability to view the entire body of the mandible which is a great help in locating the mental foramen due to ability to follow the course of the inferior alveolar and the mental canal which also aid the visualization of the foramen (Philips et al. $1992^{2}$ ).

Many studies have analyzed the position of the mental foramen in different population groups and showed that variations do exist (Santini and Alayan, 2012; Hasan, 2010). The results of this study showed that in most of the cases mental foramen was located between the longitudinal axes of the first and second mandibular premolar in Southeast Serbian population. These results were in accordance with the results of Al-Shayyab et al. (2015) who studied the position in Iraqi population and Babshet et al. (2015) in Indian population. Similar results were obtained in the studies of Philips et al. $\left(1990 ; 1992^{1} ; 1992^{2}\right)$ who reported the most common position between the apices of the two premolars in 36 to $70 \%$ of the cases. They determined the position of the mental foramen directly below the crown of the second premolar but mesial shift of the foramen was caused by distal curvature of the root apex of this tooth. Santini and Alayan (2012) compared the position of the mental foramen in three populations. They showed that the most common position in Indian population was between two premolars. According to them, European population also showed the position between mandibular premolars, while the most common position in Chinese population was in line with the second premolar. The position below the second premolar was also reported in Moroccan, Iranian, Saudi and Malay population (Chkoura and Wady, 2013; Khoyastepour et al. 2015; Al-Jasser and Nwoku, 1998; Ngeow and Yuzawati, 2003). Hasan (2010) has analyzed the position in different populations and found the most common position between the first and the second premolar in Japanese, Byzantimus, Israelis and Caucasian populations. The position below the second premolar was found in Turkish, Malawian and Mongoloids, whereas the foramen was found to be placed more posterior in blacks, between the second premolar and first molar.

In this study, an attempt to correlate the position of the mental foramen with the gender was made. However, the results were not significant since there was not correlations between the horizontal position of the foramen and gender. These results were in accordance with the results of Babshet et al. (2015) in Indian population and Amorim et al. (2008) in Brazilian population.

This study showed that the most common shape of the mental foramen was round in $54 \%$ of the cases, followed by oval shaped foramen in 39\%. This findings are consistent with results of Al-Shayyab (2015), Al-Khateeb et al. (2007) and Singh and Srivastav (2010) and agree with results reported on Iraqi, Jordanian and Indian populations. However, this results disagree with the findings of Igbigbi and Lebona (2005), Mbajiorgu et al. (1998) and Souaga et al. (2004) who found that the most common shape in Malawian, black Zimbabwean and Ivory Coast populations was oval. 
The most common position of the mental foramen in Southeast Serbian population was between the longitudinal axes of the first and second mandibular premolar. The most common shape was round. The position and shape in most of the cases were symmetrical. No statistically significant correlation of the position and shape with gender was observed. Considering the most common position of the mental foramen and the possible complications, this area should be well thought out while planning the invasive procedures in this region.

Acknowledgement.This work has been supported by the grant No. 175102 of the Serbian Ministry of Science.

\section{References}

Al Jasser, N. M., Nwoku, A. L. (1998). Radiographic study of the mental foramen in a selected Saudi population. Dentomaxillofac Rad, 27, 341-343.

Al-Khateeb, T., Al-Hadi Hamasha, A., Ababneh, K. T. (2007). Position of the mental foramen in a northern regional Jordanian population. Surg Radiol Anat, 29, 231-237.

Al-Shayyab, M. H., Alsoleihat, F., Dar-Oden, N. S., Ryalat, S., Baqain, Z. H. (2015). The mental foramen I: radiographic study of the anterior-posterior position and shape in Iraqi population. Int J Morphol, 33, 149-157.

Amorim, M. M., Prado, F. B., Borini, C. B., Bittar, T. O., Volpato, M. C., Groppo, F. C., et al. (2008). The mental foramen in dentate and edentulous Brazilian's mandible. Int J Morphol, 26, 981-987.

Babshet, M., Sandeep, R., Burde, K. Nandimath, K. (2015). Evaluation of the position of mental foramen and its correlation with age in selected Indian population using digital panoramic radiograph. International Journal of Dental Sciences and Research, 3, 87-91.

Berberoglu, H. K., Ak, G., Brkić, A., Eyupoglu, E. (2011). An endodontic overfilling occupied the foramen mentale- A case report. Int Journal of Contemporary Dentistry, 2, 109-112.

Chkoura, A., Wady, W. E. (2013). Position of the mental foramen in Moroccan population: A radiographic study. Imaging Sci Dent, 43, 71-75.

Greenstein, G., Tarnow, D. (2006). The Mental Foramen and Nerve: Clinical and Anatomical Factors Related to Dental Implant Placement: A Literature Review. J Periodontol, 77, 1933-1943.

Hasan, T. (2010). Characteristics of the mental foramen in different populations. The Internet Journal of Biological Anthropology. 4, 1-7.

Igbigbi, P.S., Lebona, S. (2005). The position and dimensions of the mental foramen in adult Malawian mandibles. WAJM. 24, 184-189.

Khojastepour, L., Mirbeigi, S., Mirhadi, S., Safaee, A. (2015). Location of mental foramen in selected Iranian population: A CBCT assessment. Iran Endod J, 10, 117-121.

Mbajiorgu, E. F., Mawera, G., Asala, S. A., Zivanovic, S. (1998). Position of the mental foramen in adult black Zimbabwean mandibles: a clinical anatomical study. Centr Afr J Med, 44, 24-30.

Ngeow, W. C., Yuzawati, Y. (2003). The location of the mental foramen in a selected Malay population. J Oral Sci, 45, 171-175.

Ngeow, W. C. (2010). Is there a "safety zone" in the mandibular premolar region where damage to the mental nerve can be avoided if periapical extrusion occurs? J Can Dent Assoc, 76, a61.

Philips, J., L., Weller, R. N., Kulild, J. C. (1990). The mental foramen: Part I. Size, orientation, and positional relationship to the mandibular second premolar. $J$ Endod, 16, 221-223.

Philips, J. L., Weller, R. N., Kulild, J. C. $\left(1992^{1}\right)$. The mental foramen: Part II. Radiographic position in relation to the mandibular second premolar. J Endod, 18, 271-274.

Philips, J. L., Weller, R. N., Kulild, J. C. $\left(1992^{2}\right)$. The mental foramen: Part III. Size and position panoramic radiographs. J Endod, 18, 383-386.

Santini, A., Alayan, I.A. (2012). A comparative anthropometric study of the position of the mental foramen in three populations. Br Dent J, 212, E7.

Singh, R., Srivastav, A. K. (2010). Study of position, shape, size and incidence of mental foramen and accessory mental foramen in Indian adult human skulls, Int J Morphol, 28, 1141-1146.

Souaga, K., Adou, A., Angoh, Y. (2004). Topographical and morphological study of the mendibular foramen in black Africans from the Ivory Coast. Odontostomatol Trop, 27, 17-21. 


\title{
FORAMEN MENTALE - HORIZONTALNA POZICIJA I OBLIK U POPULACIJI JUGOISTOČNE SRBIJE
}

\author{
Jelena Popović, Marija Daković Bjelaković, Jovanka Gašić, Marija Nikolić, \\ Milan Spasić, Aleksandar Mitić, Radomir Barac
}

\begin{abstract}
Sažetak. $\quad$ Foramen mentale je važan anatomski detalj i poznavanje njegove pozicije je značajno u stomatologiji u procedurama davanja lokalne anestezije, kod hirurških i endodontskih zahvata, kao i u forenzici. Cilj studije je bio da se utvrdi najčešća pozicija i oblik foramena mentale u populaciji jugoistočne Srbije. Analizirano je 300 panoramskih snimaka na kojima je horizontalna pozicija određivana pomoću referentnih linija koje su prolazile duž aksijalnih osa prvog i drugog donjeg premolara i mezijalnog korena donjeg prvog molara. U $62 \%$ slučajeva foramen mentale je bio lokalizovan u oblasti između prvog i drugog donjeg premolara, u 21 $\%$ slučajeva nalazio se u nivou donjeg drugog premolara, kod $9 \%$ u nivou donjeg prvog premolara, u $8 \%$ u regiji između drugog premolara i prvog molara. U $54 \%$ slučajeva foramen mentale je bio okruglog oblika. U $26 \%$ slučajeva uočena je asimetrija pozicije foramena mentale na levoj i desnoj strani mandibule, dok je asimetrija oblika uočena kod $32 \%$ pacijenata. Najčešća pozicija foramena mentale je bila u regiji između prvog i drugog donjeg premolara, dok je najčešći oblik bio okrugao. Poznavanje varijabilnosti pozicije foramena mentale je od značaja u dijagnozi i kliničkim procedurama u oblasti mandibule.
\end{abstract}

Ključne reči: foramen mentale, mandibula, panoramski snimak 